\title{
DIVORCE IN ENGLAND, THE UNITED STATES AND CANADA
}

The report of the Royal Commission on Divorce and Matrimonial Causes in England presented to Parliament on November 2, I9I2, and, forming, with the evidence and the appendices, five stout volumes (Cd. 6478), is a document of singular value for people on both sides of the Atlantic. The eminence of the commissioners, the mass of testimony from persons representing different religious bodies, lawyers, social workers, and, in short, all sections of the community likely to have special views or to be in possession of useful information, which is here carefully sifted, and the elaborate reasons on which the commissioners base their recommendations, combine to make the report a study of high interest not only for those particularly concerned with the reform of the divorce laws, but for all who wish to understand the social condition of England in IgI2.

To American readers the report is especially interesting from the remarkable agreement of the conclusions reached by the majority with those embodied in the United Divorce Law adopted by the National Congress at Washington in 1906.

It is well known that the prime mover in bringing about the appointment of the English Royal Commission was Lord Gorell, formerly President of the Probate, Divorce and Admiralty Division of the High Court of Justice, who was appointed chairman of the commission, and by whom the report was drafted in which the majority of the commissioners concurred.

Among the signatories of the majority report in addition to the chairman are Mr. Thomas Burt, one of the most universally respected leaders of the labor movement in England; Lord Guthrie, a judge of the Court of Session in Scotland; Sir Frederick Treves, the well-known surgeon; Lady Frances Balfour, and Mrs. Tennant, who was formerly a government inspector of factories. Looking to the composition of the commission it was hardly to be expected that the report should be unanimous, and it is indeed matter of surprise that of the twelve members, nine concurred in recommendations of a somewhat radical nature.

A minority report is signed by the Archbishop of York, by Sir William Anson, whose name is so well known to lawyers, and by 
Sir Lewis Dibdin, the Judge of the Arches Court of Canterbury.

The report of the minority presents with much fairness, mocleration and ability what may be called without the least idea of disparagement, the ecclesiastical view of divorce. The Archbishop of York and his colleagues point out that in the marriage service the spouses take each other "for better for worse, for richer for poorer,-till death us do part". ${ }^{1}$ They admit, however, that it is too late to expect the law to maintain the absolute indissolubility of marriage and that divorce for adultery must be regarded as finally established. "The repeal of the existing Divorce Acts even if desirable is not practicable". They admit also with perfect frankness that Parliament is boun! to consider in the amendment of the Divorce Law not only the views of those who upon religious grounds are opposed to divorce, but the opinion of persons of every variety of creed and of no creed, and that the question must be treated "on the broad grounds of the real interests of the whole community and with reference to the actual conditions of our day." The minority found strong'y upon what they hold to be the lessons of experience. They point to the facts that in the Roman Empire freedom of divorce was. the corroding plague of society, and that in the countries which in modern times have increased the facilities for dissolving marriage there has been a marked increase in the number of divorces. In France the number has increased between 1886 and 1906 from 2,950 to 10,503 per annum. But, as might be expected from their point of view, it is the situation in the United States with its divorce rate in 1906 of 86 per 100,000 of the population, which. is the most conspicuous warning against giving increased facilities for divorce. "We cannot but be profoundly influenced by the example of America, governed by divorce laws the working of which has, as a matter of fact, been followed by a state of things regarded by most Americans with profound regret and alarm, but an effective improvement of which no one discerns how to effect. $* * *$ The experience of other countries and especially of America certainly does not encourage the hope that the public good of this nation will be promoted by the enactment of extended grounds of divorce." They deny that there is any suf-

\footnotetext{
1 It is worth noting that " $\mathrm{dc}$ part" is a rather clumsy innovation. Until 1662 the Prayer Book said "till death us departe" where that word is used: in its old sense of divide.
} 
ficient evidence of a popular demand in England for such an extension, and contend that the recommendations of their colleagues to allow divorce for several causes in addition to adultery are not based upon any solid principle. If the doctrine of the indissolubility of marriage is to be given up, the only logical conclusion is that divorce should be granted on the mutual consent of the parties, and this would involve the disintegration of the family. Though differing toto coelo from the majority on the fundamental question of increasing the causes of divorce, the minority nevertheless concur in the recommendations of the majority upon several important points. They concur with them that in order to make divorce available for the poor as well as the rich, local divorce courts ought to be established in which divorce can be obtained at much less expense than at present. It is, they say, incontestable that no one ought to be deprived of his legal rights merely by poverty. They concur in the recommendation that the wife should be entitled to a divorce from the husband on the ground of his adultery without the necessity of proving, as at present, either cruelty or desertion in addition, or that the adultery was incestuous or bigamous, or was an act of rape. There was a very strong body of testimony in favor of introducing equality as between the sexes in this matter, and the report, unanimous upon this point, says, "The social and economic position of women has greatly changed in the last hundred and even the last fifty years. The Married -Women's Property Act, I882 (which gave the wife control of her separate estate), has given them a new status in regard to property: they engage freely in business and in the professions, and in municipal, educational and poorlaw administration, and claim equality of treatment with men. In our opinion it is impossible to maintain a different standard of morality in the marriage relation without creating the impression that justice is denied to women, an impression that must tend to lower the respect in which the marriage law is held by women." At present the English law takes the view of Dr. Johnson, of whom Boswell narrates: "I mentioned to him a dispute between a friend of mine and his lady, concerning conjugal infidelity, which my friend had maintained was by no means so bad in the husband as in the wife. Johnson: 'Your friend was in the right, sir. Between a man and his Maker it is a different question: but between a man and his wife, a husband's infidelity is nothing. 
They are connected by children, by fortune, by serious considerations of community. Wise married women don't trouble themselves about infidelity in their husbands.' Boswell: 'To be sure there is a great difference between the offence of infidelity in a man and that of his wife.' Johnson: 'The difference is boundless. The man imposes no bastards upon his wife." "

A number of witnesses before the Commission expressed the view that an act of adultery on the part of a man has not the same significance as an act of adultery on the part of a woman, and that an act of adultery on the part of a man may be more or less "accidental". . But this opinion does not appear to be shared by women, and the Commissioners say: "We have had no evidence of difference of opinion among women on this matter, and we understand that women of all classes and all shades of religious and political opinion are unanimously in favor of equality of remedy in matrimonial causes." In a letter sent to the Commission by a very large organization of women, the champions of "accidental" adultery are presented with a rather neat dilemma. "Whether, and how far, misconduct on the part of a man may be regarded as accidental, may perhaps be considered in the light of the question as to with whom such "accidental" misconduct is likely to take place. Misconduct with a pure woman would imply a very deliberate and sedulously pursued intention: with an immoral one, a choice of company, which in itself, even before the commission of the act, could not be held consistent with due regard for the rights of the wife, or family, or of society. Along the path of dalliance 'accidents' belong to the category of high probabilities."

This venerable rule of inequality is preserved in the law of Quebec where a husband may demand a permanent sepparation on the ground of his wife's adultery, but the wife can demand the separation on the ground of the husband's adultery only if he keep his concubine in the common habitation of the spouses. This was also the law of France until I884. It is true that in Quebec as in France, the Court may grant separation on the ground of "grievous insult"-injures graves, -and the public and notorious adultery of the husband is held by the judges to be covered by these words. But if the husband conducts his adultery with discretion the wife has no legal remedy.

Since Dr. Johnson's time the advance of medical science has greatly shaken public confidence in the harmlessness of "acci- 
dental" adultery. As the Commissioners say: "In continuous adultery the mistress may otherwise be a pure woman, and, regarded in its medical aspects, the adultery may be a source of no physical danger to the wife. But a single act of adultery, that which might come under the term "accidental" as used in evidence, is, as likely as not, committed in circumstances which give rise to every possible risk of infecting a man with venereal disease, and, by reason of such infection, a wife's health and that of her children may be most seriously affected, or sterility may be produced." It may be confidently expected that one result at least of the Royal Commission will be the abolition of the old distinction in England between the legal effect of the adultery of the wife and that of the husband. It by no means follows that women will be as ready to seek their legal remedy for this cause as men. In Scotland the distinction is not made, but Lord Salvesen, speaking from his experience as a judge in that country, says: "We do not find that women as a rule take proceedings against their husbands for what may be called casual acts of adultery, but only when the marriage relation has become intolerable upon other grounds. $* * *$ At the same time I think the wife should have the remedy if she desires to exercise it and that in many cases it operates very much in the direction of promoting public morality." The Commissioners were unanimous also in certain recommendations in regard to the law of presumption of death. These recommendations were, (I) that if a party to a marriage had been continually absent from the other party for seven years and not known by such party to be living within that time, this other party should be entitled to apply to the Court for an order of presumption of death, and, on obtaining such order, should be entitled to contract a valid second marriage; and (2) that where the husband or wife had disappeared in circumstances which would justify any reasonable person in believing that he or she were dead, although the absence may not have continued for the seven years, the judge, if satisfied that there is reasonable ground for declaring that the absentee is dead, may make an order to that effect, upon which order the other shall be entitled to make a valid second marriage. The minority further concurred with the majority in regard to amendments of the law as to nullity of marriage. The following grounds are recommended as sufficient to justify a petition by a party to a marriage for a declara- 
tion of nullity provided the suit is brought within a year of the marriage, and that the petitioner at the time of the marriage was unaware of the fact founded upon: (I) When the other party, though of sufficient understanding to consent to a marriage was, at its date, either of unsound mind in other respects, or in a state of incipient mental unsoundness which becomes definite within six months after marriage; (2) When the other party at the time of the marriage was subject to epilepsy or to recurrent insanity; (3) When the other party was at the time of the marriage suffering from a venereal disease in a communicable form; (4) When the wife is found to be pregnant at the time of marriage by some man other than her husband. It is also a unanimous recommenclation that when no intercourse between husband and wife has taken place wilful refusal without reasonable cause to permit intercourse should be made a ground for the decree of nullity. In this case the right to bring the suit is not limited to the period of one year after the marriage. It will be observed that these suggested grounds of nullity in addition to those now recognized, such as impotence, consanguinity, prior marriage and spouse living, duress, insanity, and an erroneous belief as to the nature of the ceremony, are considerably broader than those formulated in the uniform law, except in so far as some of them may be held to be covered under "fraud". The statutory declaration of the grounds suggested by the Royal Commission would seem to be calculated to prevent a person mentally or physically unfit for marriage from taking advantage of the innocent partner. The last recommendation in which there is no disagreement deals with the very vexed question of the reporting of divorce cases in the newspapers. It is recommended that a judge should have power to close the Court for the whole or part of the case if the interests of decency, morality, humanity, or justice so require, or to order that a portion of the evidence should not be reported: that no reports of the divorce proceedings should be published until after the close of the case, and that the publication of pictorial representations of parties, witnesses or those otherwise concerned in divorce cases should not be permitted. Publications contrary to the statute giving effect to these recommendations would render the person infringing liable for contempt of Court.

I have thought it convenient to notice in the first place the recommendations which are unanimous, because it is believed in 
well-informed circles that the government proposes to introduce a bill giving effect in the first instance only to the recommendations in which all the Commissioners concur, while deferring for further consideration the more radical recommendations of the majority. These recommendations may now be explained briefly.

According to the existing English law the only ground of -divorce $a$ vinculo at the instance of the husband is the adultery of the wife, and at the instance of the wife, the adultery of the husband, if coupled with cruelty or desertion for two years, or, if there are certain other aggravations of a gross chairáctèr (20 and 2I Vict., c. 85, s. 27). A sentence of judicial sepàration, corresponding with what is generally called in America a limited divorce, may be obtained either by the husband or the wife for adultery or cruelty, or desertion without cause for two years and upwards (20 and 21 Vict., c. 85, s. I6). The majority recommend to begin with that the grounds which are at present sufficient for judicial separation should be made sufficient for divorce . $a$ vinculo, except that they would extend the period of desertion to three years instead of two, whichever remedy was sought. Under the present law of England, when cruelty has to be estabilished as a makeweight in addition to the adultery of the husband, the Courts are, naturally enough, inclined to treat evidence rof cruelty of a somewhat slight character as sufficient. According to French experts injures graves is likewise a term of very -elastic definition. The Commissioners are anxious to make it clear that in recommending that cruelty should be made a substantive ground of divorce they mean cruelty of a really serious character, and they suggest the following definition: "Cruelty is such conduct by one married person to the other party to the marriage as makes it unsafe, having regard to the risk of life, limb, or health bodily or mental, for the latter to continue to live with the former." In addition to adultery, desertion, and cruelty, they recommend three entirely new grounds of divorce, viz., incurable insanity after five years confinement, habitual drunkenness found incurable after three years from an order of separation, and imprisonment under commuted death sentence. The list of grounds would therefore be the same as those given in the Uniform Law, with the addition of incurable insanity, except, that under the Uniform Law, imprisonment for two years is sufficient, and that under the Uniform Law the period-of desertion and of habitual drunkenness is two years instead of three. 
Of the new causes recommended by the Royal Commission as grounds of divorce incurable insanity is the most debatable. In all the other cases divorce is granted on the ground of the misconduct of the other spouse. Here it is proposed that the marriage may be dissolved on the ground of an innocent misfortune. It is argued by many that if divorce were to be allowed on the ground of insanity there is no reason in principle why it should not be allowed for paralysis, phthisis, or certain other diseases. It is pointed out by some of the medical experts that insanity is. simply a bodily disease which manifests itself in mental derangement. On the other hand the Commissioners meet this argument by saying that the position of the insane is very different from: that of other diseased persons. The incurably insane have to be removed from their homes and the continuance of family life is. impossible. Sufferers from other diseases may still be companionable, but the incurably insane are in most cases practically dead as far as the home is concerned. In the letters printed in the Appendix there are pathetic accounts of young working mers whose wives are confined in asylums, being left with young children to take care of and unable to marry a woman who could look after them. That there is a substantial difference between insanity as affecting the marriage relation and other diseases seems to be indicated by the fact that insanity is a ground of divorce in many countries, Germany, Norway, Sweden, Switzerland, New Zealand, Bulgaria, Denmark, Russia, and in the States of Idaho, Maine, Utah and Washington. The majority of the English: Commissioners find that the medical evidence clearly shows that if the ground is confined to lunacy pronounced incurable after five years continuous confinement the risk of miscarriage of justice from the recovery of the patient is almost negligible. They recommend, however, that insanity should not be a ground, when the age of the insane person is, if a woman, over fifty years, and if a man, over sixty years. This is to exclude the case of senile dementia, and cases, where, having regard to the age of the parties, there is no reasonable ground for dissolving the marriage. It hardly appears necessary to enter upon any discussion of cruelty, desertion, or habitual drunkenness as grounds of divorce. If we accept the premise that whatever is admitted as a sufficient legal cause for a permanent separation between the parties should be accepted as a ground of divorce $a$ vinculo these cases raise no. 
difficulty. And unless we elevate the indissolubility of marriage into a dogma there does not seem to be any valid reason for rejecting this conclusion. ${ }^{2}$ It may be regarded as certain, however, that public opinion in England is as yet hardly prepared for changes in the law of so drastic a character. The Report of the Commission will be widely read and discussed, and $I$ am inclined to think that in the long run most of the recommendations of the Commissioners will be adopted, but the forces of conservatism in that country are very strong, and the great political and social influence of the Established Church will be employed to resist any changes except those as to which the minority report concurs with the report of the majority.

The main battle may be expected to be with regard to the question whether an increase in the number of grounds of divorce will lead to divorce becoming dangerously common. It is very doubtful whether the relation between the number of causes of divorce and the number of divorces.is anything like so constant as might be supposed. No doubt if divorce becomes available to all those persons who, but for the change in the law, would have been entitled only to judicial separation they may be expected to avail themselves of the new remedy unless they belong to a church which restrains them from doing so. But, adding divorces and judicial separations together, the total number of marriages will not be increased. This subject has been investigated a good deal by statisticians and their opinion appears to be that the influence of legislation upon the number of divorces is on the whole slight. Where divorce is very frequent the causes are mainly to be sought for in other directions. A crucial instance upon this point is the comparison which has been made between Belgium and France. During the decade $1872-188$ I the number of divorces and separations in Belgium was smaller in proportion to marriages than it was in France, although in Belgium both divorce and separation were admitted, and divorce was allowed by mutual consent, whereas in France separation only was possible, and that not by

2 Permanent separation punishes the innocent as much as the guilty, and tends to cause immorality. It is an unsatisfactory and illogical compromise which would never have been thought of but for the doctrine that divorce was contrary to divine law. 
mutual consent. The two countries in regard to religion and general conditions were quite sirrilar. ${ }^{3}$

The relation between the cost of divorces and their frequency relative to the population is much more constant. Mr. Willcox says: "The one efficient means of reducing the number of divorces by law is to make them expensive. The evidence demanded will be furnished but the money may not." This statement is amply borne out by all the available evidence. Wherever divorce is cheap it is relatively common. In Germany, in France, in Holland, and in Scotland, a poor person who desires a divorce and has prima facie a good case, can obtain free legal assistance, and in Germany even the expenses of witnesses are provided out of public monies. It may be confidently asserted that the number of divorces has increased far more from this cause than from any alteration made by the law in the grounds of divorce.

Mr. Willcox gives an illustration which I will take the liberty of adopting: "Imagine society as a huge pyramid in which the position of each individual is determined by his knowledge and wealth. Imagine a horizontal plane intersecting the pyramid to represent the divorce law of the community, and all persons above the plane as possessing so much knowledge and money that divorce is to them a theoretical possibility, while to those below it is not. If the plane be motionless the rate of increase of divorce may be found; but if it be gradually sinking towards the base of the pyramid and making divorce a practical possibility to an increasing proportion of the whole number, this change must affect the calculation." As he says, such a descent of the divorce plane has been in progress in the United States for many years.

The fallacy which vitiates to a very great extent the value of comparisons between the divorce statistics of different countries is that we may be comparing the figures of a country in which divorce is within the reach of the mass of the population with those of a country in which it remains the luxury of the rich. Nothing appears more clearly from the evidence presented to the Royal Commission in England than the fact that in that country a very large number of people dispense with divorce simply because

${ }^{3}$ See on the subject of the influence of legisiation as increasing the number of divorces, Bertillon, Etude Démographique du Divorce, and the valuable study by Professor W. F. Willcox, "The Divorce Problem," in Columbia College Studies in Political Science, vol. 1, p. 1. New York, 1891. 
they cannot afford it. The Commissioners quote with approval a report of the County Courts Committee, which they say is entirely supported by a very large body of professional evidence. That report contains the following passage: "There is a close analogy between the state of things which still exists and that which existed before 1858 (i.e., the year in which the Divorce Court was created). For there is still practically one law for those who can afford to bring a suit in the Divorce Court and another for those who cannot, and the latter class embraces a very large portion of the population who cannot afford even the moderate expense of a suit in the present Court. The cost of bringing or defending a suit in London, and having the hearing there, renders it quite impossible for many of the poorer classes to get the relief which those better off obtain." In the United States this is not the case to anything like the same extent. Questions were submitted to a large number of American lawyers in different States. From the replies it appears that in Alabama a poor person can obtain a divorce for about forty dollars, in Connecticut for fifty dollars, in Georgia for twenty-five to fifty dollars, in Illinois for about thirty-five dollars, in Indiana for two dollars-a price possibly too tempting-in Louisiana for five dollars, and so on.. Without laying undue stress upon the precise figure there is every reason to believe that in most of the States divorce is within the reach of the mass of the people.

A striking proof of the fact that nothing keeps down the number of divorces so much as expense is found in the Canadian figures. Four of the Canadian provinces have Divorce Courts, though in one of them, Prince Edward Island, no divorce has in fact been granted for some half century. In the other provinces the only means of obtaining divorce is by an Act of the Dominion Parliament, and these provinces include six millions out of the seven and a half millions who inhabit Canada. If we compare the Canadian figures for the forty years between I867 and 1906 with those of the United States, we find that in Canada there have been $43 \mathrm{I}$ divorces as against I,274,34I in the Republic. The population in Canàda in I867 stood to that of the Jnited States about as I to I2, and that ratio has not greatly varied up to the present time. Taking this proportion as roughly accurate, the result is that divorce is in the United States more than 320 times as commion as in Canada. It would be delightful to suppose that 
we were $3^{20}$ times as virtuous as our neighbors, but there are considerations which make it difficult for us to cherish this belief. If the figures showed that we were twice or even ten times as virtuous they would confirm our deep suspicions, but three hundred and twenty is too much for the most stalwart patriot.

In fact the reasons why divorce is so excessively rare in Canada are by no means far to seek. Except in the Maritime Provinces and in British Columbia, where Divorce Courts exist, the expenseof procuring a divorce is so great as to place it altogether out of the reach of the great mass of the population. That this is the true explanation of the infrequency of divorce is clearly shown by the fact that the divorce rate in Nova Scotia is about eight times. as large as that of Ontario. In British Columbia it would seem that other causes are at work, as the divorce rate there is noticeably higher than in other parts of the country, although as regards. the grounds for obtaining divorce, it is the only province in which the wife cannot obtain a divorce for the adultery of the husband in itself. In Quebec, Ontario, and the central provinces the only remedy is, as has already been stated, to obtain an Act of Parliament dissolving the marriage. I am informed that there are few cases, even of the most simple character, in which such an Act. can be obtained for less than $\$ \mathrm{I}, 000$. The parliamentary fees themselves amount to about $\$ 300$, the proceedings are generally somewhat protracted, it is necessary as a rule to employ parliamentary agents in addition to the attorney of the petitioner, and the witnesses have to be taken to Ottawa. Moreover, there is another reason why wives, who have no independent fortunes and. are not in a position to support themselves, are excluded from obtaining a parliamentary divorce. The Act which dissolves the marriage does not provide for payment of alimony by the husband, and a wife who has obtained a parliamentary divorce cannot obtain a decree for alimony in the Provincial Courts. It follows, therefore, that the working classes are entirely unable to. obtain a parliamentary divorce because they have not the $\$ 1,000$. required, and that a large proportion of the wives of the wellto do are equally deterred by the knowledge that, if they obtain. a divorce, they will be thrown upon their own resources for their support. In regard to divorce we have therefore one law for the rich and another for the poor. It is a painful thought to: those who believe in equality in such matters that except in a few- 
modern States divorce has always been the luxury of the rich. In the palmy days of the canon law the annulling of marriages was a flourishing business, and it has been said that for a sufficient consideration a canonical flaw could be found in almost any marriage. Such cases as that of Roger Donington, whose marriage was pronounced null because before its date he had misconducted himself with a third cousin of his future wife, or another well known case in which a marriage was annulled, because the husband had stood godfather to his wife's cousin, illustrate the possibilities of escape from an uncongenial marriage. But the spiritual Courts were as expensive as they were ingenious, and for the poor, at any rate, marriage was indissoluble de facto as well as de jure. ${ }^{4}$

Enough has been said to prove that the divorce rate in Canada is quite unreliable as an index to the number of marriages which would be dissolved under a reasonable system of law. In the Province of Quebec, it is true, the paramount influence of the Roman Catholic Church would restrain a large part of the population from seeking divorce under any circumstances.

In the opinion of the writer, if the grounds of divorce are restricted to such serious causes as those which the Royal Commission would admit as sufficient, if the laws as to jurisdiction are firmly applied, and, if necessary, strengthened, so as to prevent migratory divorces, there is no need to anticipate the disintegration of society. It is quite another matter if we allow divorce at will. There are in all countries many to advocate this, but this is no new thing. The danger is in the growth of a public spirit which looks upon marriage as merely a contract terminable at will. Such writers as Professor Lichtenberger welcome this tendercy." He says "When the wife realizes that she may not call upon legal aid to retain her husband's affection, she will endeavor to maintain the qualities which made her attractive to him

* The enormities of the medixval canon law may be studied in Esmein, Le Mariage en Droit Canonique, or Freisen, Geschichte des Canonischen Eherechts. Although some of the most glaring absurdities have been removed, it is still bad enough. The canon law impedimențs still apply to the marriages of Roman Catholics in the Province of Quebec, and we have lately seen a marriage annulled on the ground that the parties were third cousins and had not obtained a dispensation. Tremblay $v$. Despatie, 1912, R. J. Q. 43 S. C. 59 . Leave to appeal to the Privy Council is being applied for in this case:

5 "Divorce," New York, 1909. 
before marriage." Has it escaped his observation that the qualities which make women attractive are sometimes youth and goorl looks, and that the endeavor to maintain these qualities, though highly laudable, is a forlorn hope? Those women who advocate that marriage should be dissoluble at will seem to me hardly to realize the risk of men taking them seriously. Students of the history of marriage are well aware that among many peoples and at many periods of the world's history marriages have been free enough in all conscience, but it has generally been supposed that the position of women was inferior then to what it is now. It is strange indeed to find women looking back to those times as the golden age in the history of the sex. The gifts and talents of most women, when all is said, form but a scanty equipment for any profession except that of a wife. If by nature, training, and temperament, they are adapted for this occupation at twenty, if they have spent ten or twenty years in its active practice, to what new career can they turn with any prospect of success? The wife who has freed herself from one marriage may marry again, but in this career the advantages of age and experience may be overrated. In the search for a husband she may be beaten by a mere beginner, and if she has to discover another way of earning her livelihood she has a hard struggle before her. Her youth is gone; she has in all probability no special knowledge of a kind which can be turned to pecuniary account, and she has to compete with her sisters who have not consumed the best years of their lives in wedlock. Uncounted ages have gone to make men recognize legalized monogamy as the keystone of the arch on which our society is built, and we are now gravely advised on the highest ethical grounds to go back to the simple manners of the savage.

If people were all high minded and reasonable, "free" marriages might indicate a higher state of morals than exists today, but the race has far to travel before this has been achieved.

F. P. Walton.

Dean, Faculty of Lazv, McGill Unizersity, Montreal. Can. 